\title{
Australian lungfish, Neoceratodus forsteri, threatened by a new dam
}

\author{
Angela H. Arthington
}

Received: 11 February 2008 / Accepted: 13 August 2008 / Published online: 5 September 2008

(C) The Author(s) 2008. This article is published with open access at Springerlink.com

\begin{abstract}
The Australian lungfish, Neoceratodus forsteri, exists as remnant natural populations in two rivers of south-east Queensland, Australia, and several translocated populations. Lungfish habitats have been impacted by agriculture and forestry, alien plants and fish and by river impoundment and regulation of flows. The species has been listed as vulnerable under Australian Commonwealth legislation. A proposal to construct Traveston Crossing Dam on the free-flowing main channel of the upper Mary River could seriously threaten the lungfish. The dam can be stopped by Commonwealth legislation if important populations of lungfish in the Mary River are likely to be significantly impacted by the new dam. This paper assembles evidence that impoundment of the Mary River and regulation of river flows are likely to decrease and fragment important lungfish populations, disrupt the breeding cycle, reduce juvenile recruitment, and isolate and decrease habitat availability/quality to such an extent that the species is likely to decline. Proposed mitigation strategies include fish transfer facilities, provision of flow releases from the dam (environmental flows) to sustain lungfish habitat and breeding down-
\end{abstract}

A. H. Arthington $(\bowtie)$

Australian Rivers Institute and eWater Co-operative

Research Centre, Griffith University,

Nathan, Queensland 4111, Australia

e-mail: a.arthington@griffith.edu.au stream, and translocation of hatchery-reared juvenile lungfish into suitable natural habitats. These mitigation efforts may not be sufficient to secure the genetic diversity and long-term viability of lungfish populations in the Mary River.

Keywords Lungfish . Threatening processes · Traveston Crossing Dam · Queensland

\section{Introduction}

Neoceratodus forsteri, commonly called the Australian or Queensland lungfish (Fig. 1), has attracted tremendous scientific interest since Australian Museum biologist Gerard Krefft first described it as a 'gigantic amphibian' (Krefft 1870). The Australian lungfish is the most primitive surviving member of the ancient and once speciose air-breathing Dipnoi (lungfishes) that flourished in the Devonian (ca. 413-365 m.y.b.p), a lineage now represented by $N$. forsteri (Family Ceratodontidae), one South American species (Family Lepidosirenidae) and four African species (Family Protopteridae; Tokita et al. 2005; Nelson 2006). Fossil records indicate that the range of $N$. forsteri extended to the centre of the Australian continent prior to the Pleistocene (Kemp 1991) but today the Australian lungfish occurs naturally only in the Burnett and Mary rivers in south-east Queensland, and as several self- 
Fig. 1 The Australian lungfish, Neoceratodus forsteri (Krefft 1870). Drawing by Dr Bradley J. Pusey, Australian Rivers Institute, Griffith University, Nathan QLD 4111, Australia

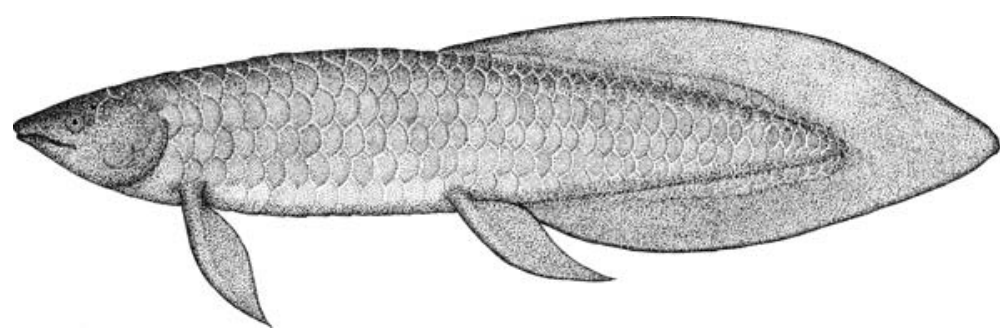

sustaining populations descended from translocations of Burnett and Mary River stocks in the 1890s (Fig. 2). Translocated populations are found in the North Pine River (and North Pine Dam), the Brisbane River catchment (e.g. upstream, in and downstream of Lake Wivenhoe, and in Enoggera Reservoir) and in the Coomera River, south of the natural range (Fig. 2). Rivers supporting the lungfish have been modified and degraded by land clearing, forestry, grazing, agriculture, horticulture, loss and fragmentation of riparian corridors, bank erosion, gravel and sand extraction, channelization, urbanization, spread of alien plants and fish, and by river impoundment and regulation of river flows (Arthington et al. 1983, 2000; Kemp 1995; Pusey et al. 1993; Mackay et al. 2003; Kennard et al. 2005). Consequently $N$. forsteri is considered to be threatened throughout most of its range (Kemp 1995) and has been listed as 'vulnerable' under Australian Commonwealth legislation (Department of Environment, Water, Heritage and the Arts 2008). This listing is intended to protect the lungfish from further disturbance of its natural habitats and to foster recovery actions. Yet a new threat lies ahead for Mary River populations in the form of a large dam on the main channel-the proposed Traveston Crossing Dam (Fig. 2). This communication is focused on the potential impacts of the new dam on lungfish populations in the Mary River and implications for the conservation of $N$. forsteri. It extends and updates an earlier contribution to 'Threatened Fishes of the World' by Kemp (1995) and draws upon a detailed account of the biology and conservation status of the lungfish published in 'Freshwater Fishes of North-Eastern Australia' (Pusey et al. 2004).

\section{Conservation status of the lungfish}

Neoceratodus forsteri is a sacred (totemic) fish of the Gubbi Gubbi Aboriginal people living in the Mary River catchment who call the lungfish 'Dala' and have revered and protected it from harm for thousands of years. It has been fully protected by the Queensland Fish and Oyster Act since 1914 and was placed on the CITES list in 1977 (Kemp 1995). Fishing for lungfish is prohibited and collection for educational or research purposes requires a permit from the State of Queensland under the Fisheries Act 1994. The lungfish was formally listed as a Vulnerable species under the Environment Protection and Biodiversity Conservation Act 1999 (Cth; EPBC Act) in 2003. This designation means that any action or activity likely to have a significant impact on important populations of the lungfish must be referred to the Commonwealth Department of the Environment, Water, Heritage and the Arts (DEWHA) for permission to proceed or not, or to proceed under specified conditions. For details of the EPBC Act and case histories of its applications see homepage at http://www.environment.gov.au/epbc and McGrath (2006).

The most recent development action that may threaten the lungfish within its natural range is the proposed Traveston Crossing Dam on the main channel of the Mary River about $27 \mathrm{~km}$ upstream from the town of Gympie (Fig. 2). This dam is planned in two stages. When completed in 2011 stage 1 of the dam will have a Full Supply Level (FSL) of EL $71 \mathrm{~m}$ (Australian Height Datum) and at this FSL would inundate approximately $36.5 \mathrm{~km}$ of the main river channel and lower reaches of several tributaries where lungfish live and breed (SKM 2007). The stage 1 dam will hold approximately $153,700 \mathrm{Ml}$ of water, of which about $70000 \mathrm{Ml}$ per annum would be piped to the Sunshine Coast or the city of Brisbane (Fig. 2). Stage 2 of Traveston Crossing Dam is planned for completion by 2035. At an FSL of 79.5 the stage 2 impoundment will be able to store about 570,000 Ml and will inundate $50.7 \mathrm{~km}$ of the main river channel. Traveston Crossing Dam is intended to help secure water supplies for the south-east corner of Queensland, where rapid population growth, prolonged drought and 


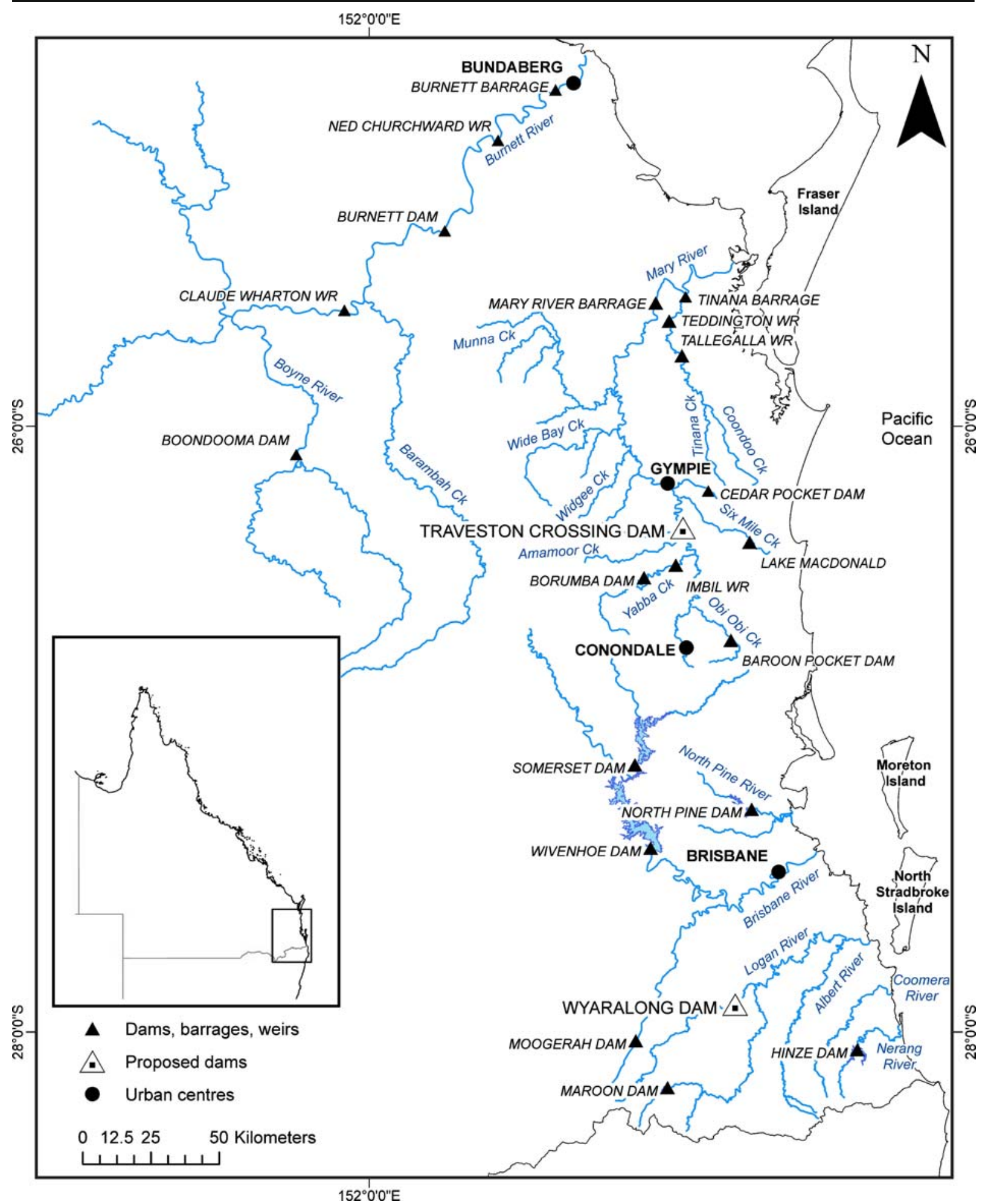

Fig. 2 Map of south-east Queensland showing the Mary, Burnett, North Pine, Brisbane and Coomera Rivers and the place names and dams mentioned in the text 
climate change are creating severe water shortages and citizens are demanding solutions (for more detail see Meredith 2008a, b).

Members of the local, regional and national community are deeply anxious about Traveston Crossing Dam and its environmental and social impacts on the Mary River and regional ecosystems. Threats to the Australian lungfish have also attracted global attention (e.g. Daeschler et al. 2006; Editorial Nature 442 2006; Pearson 2006). A special petition established in late 2006 by Professor Jean Joss from Macquarie University has gathered over 7,600 signatures and numerous individual expressions of concern (see http://www.thepetitionsite.com/1/a-veryspecial-fish-australian-lungfish-under-threat). In her introduction to the petition Joss (2007) says:-

'The significance of the Australian lungfish cannot be overstated. As a living fossil it provides the only opportunity to study the development and physiology of the aquatic predecessors of all land vertebrates, including ourselves. Australia is the custodian of this invaluable information source for the rest of the world. The answer to Queensland's water problem lies in education on water use and smart new technologies, not in damming a fragile coastal river system and willfully extinguishing a uniquely important animal'.

Helen Pearson (2006) writing for Nature echoes these comments:-

'Like all primitive fishes it has a lung, as well as gills. The immediate (but not very close) relatives of the lungfish include the coelacanth as well as the ancestors of all land-living vertebrates. This makes the lungfishes 'living fossils' of great value in studying the biology of the earliest ancestors of land animals (see B. Daeschler et al. Nature 440, 757-763; 2006). Studying the species may provide a unique insight into how our own vertebrate ancestors made the journey from water to land'.

\section{Potential impacts of Traveston Crossing Dam}

If Traveston Crossing Dam is permitted to proceed it is very likely that it will cause significant harm to important populations of the Australian lungfish in the Mary River. Under the EPBC Act an important population is one that is necessary for the species' long-term survival and recovery, and may include key source populations for breeding or dispersal, populations that are necessary for maintaining genetic diversity, and/or populations that are near the limit of the species range (Anon 2006).

The natural geographic range of the lungfish is limited to the Burnett River (420 km from source to sea) and the Mary River (307 km from source to sea) with the Mary supporting the most southern natural populations and the Burnett River being the northern limit of the natural range (Fig. 2). All populations recorded further south are almost certainly translocated (Frentiu et al. 2001; Pusey et al. 2004). Populations in the Mary and Burnett rivers are geographically isolated by a catchment divide and lack of a common lowland confluence (Fig. 2). The lungfish cannot live in saline water nor migrate through seawater, making the separation of the two present-day catchments and populations of $N$. forsteri absolute (Pusey et al. 2004). The Mary River therefore supports an independent breeding population of $N$. forsteri. Although allelic diversity at allozyme and mtDNA loci is low (average heterozygosity across all loci is 0.03), Frentiu et al. (2001) discovered significant genetic variation within the Mary and Burnett river systems, and recommended conservation of all populations in the two rivers to protect the total genome. These considerations (distribution limits, contribution to breeding stocks and protection of genetic diversity) establish that lungfish populations in the Mary River are important for the species' long-term survival and recovery. They satisfy all three importance criteria established under the EPBC Act (Anon 2006).

An Environmental Impact Statement (EIS) has been completed for the Traveston Crossing Dam (SKM 2007) and is currently being evaluated by DEWHA for the evidence it presents concerning likely significant impacts on important populations of the lungfish and other threatened species and ecosystems. The EIS is overwhelmingly positive, making the case that any possible impacts on lungfish populations have been addressed during the assessment process and can be mitigated (see section on mitigation options below). Formal submissions to DEWHA on the EIS present a very different 
perspective. Many make the case that Traveston Crossing Dam is very likely to have significant impacts on lungfish populations in the Mary River. A significant impact under the EPBC Act may involve any or all of the issues discussed below.

1. The dam will have adverse effects on lungfish habitat

Lungfish occur and are common in the Mary River main channel from the tidal barrage (a $2.9 \mathrm{~m}$ high barrier constructed to impound freshwater and prevent upstream movement of tidal flows, situated $59 \mathrm{~km}$ from the mouth of the river) to the town of Conondale $220 \mathrm{~km}$ from the river mouth (Brooks and Kind 2002; Fig. 2). Lungfish also inhabit large tributaries including Yabba, Obi Obi, Six Mile and Amamoor Creeks in the upper catchment, and western tributaries such as Wide Bay, Widgee and Munna Creeks, as well as the Tinana/Coondoo system (Fig. 2). Adult lungfish are usually found in flowing stream and river reaches with overhanging riparian vegetation along the banks, woody debris in the water and dense macrophyte beds (Fig. 3). The stage 1 impounded area will inundate $36.5 \mathrm{~km}$ (about 22\%) of this type of habitat along the Mary River main channel upstream from Gympie, and will also extend into lungfish territory in several of the tributaries named above. Resting, feeding, spawning and juvenile habitats in the main channel will all go under water to an average depth of about $5 \mathrm{~m}$. Although impoundments can provide habitat and feeding grounds for mature lungfish, far more fish have been captured in the headwater sections of ponded areas where there are shallow waters and more complex habitat structures than in deeper impounded areas (Brooks and Kind 2002).

When Traveston Dam fills the impounded water will not only inundate preferred main channel and tributary habitat for lungfish but will also spill out of the main channel to flood surrounding low lying terrain and create a number of shallow bays, with about $25 \%$ of the impounded area likely to be less than $2 \mathrm{~m}$ deep (SKM 2007). Areas of still, shallow, nutrient rich water are likely to be colonized by aquatic vegetation (Duivenvoorden 1998; Mackay et al. 2001) however the preferred complex of species, vegetation structure and density may not resemble that found in unregulated river reaches. Lungfish show a preference for shallow but dense beds and banks of Vallisneria gigantea and Hydrilla verticillata mixed with floating-leaved species such as Ludwigia peploides, Nymphaea and Nymphoides (Kind 2002). There is concern that alien weedy species already present in the Mary catchment (Cabomba caroliniana, Eichhornia crassipes, Egeria densa and Salvinia molesta) will become established and spread in the Traveston impoundment and interfere with the development of natural vegetation stands preferred by lungfish. Furthermore, newly inundated embayments will initially, and for some time, lack or have very little overhanging riparian canopy, and the littoral
Fig. 3 Mary River main channel lungfish habitat. Photograph by Dr Mark J. Kennard, Australian Rivers Institute, Griffith University, Nathan QLD 4111, Australia

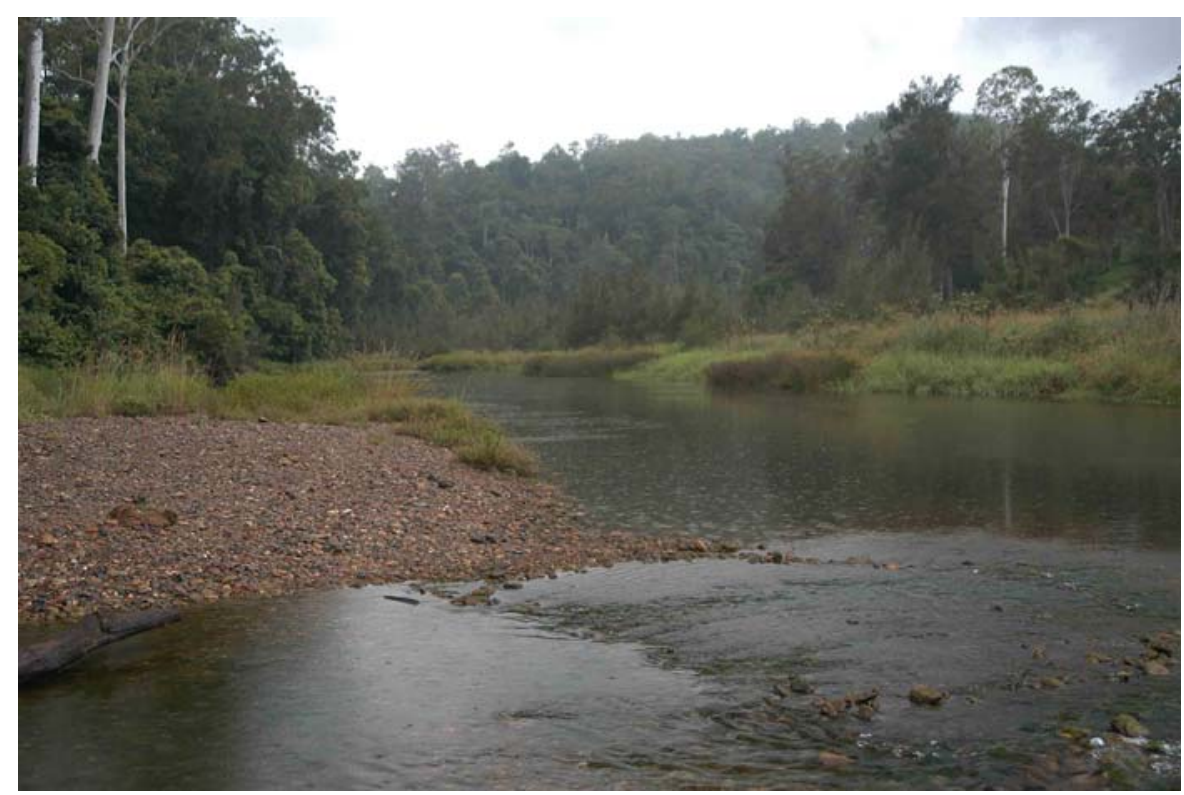


vegetation that does develop may never recover the full range of ecological functions normally provided by natural riparian corridors. These functions include shading, temperature control, contributions to bank stability and aquatic habitat structure/diversity, supply of woody debris and transfer of energy from the terrestrial environment into aquatic food webs (Pusey and Arthington 2003).

2. The construction of Traveston Dam and inundation of core breeding habitat will disrupt the breeding cycle of the lungfish

Lungfish spawning requirements

Neoceratodus forsteri is very selective in the choice of spawning site (Kemp 1986; 1995). Highest densities of early stage embryos are typically associated with intermediate flow velocities $\left(0.2 \mathrm{~m} \mathrm{~s}^{-1}\right)$, low turbidity, a broad range of temperatures (maximum $36^{\circ} \mathrm{C}$.), high dissolved oxygen levels, depths of 40 $60 \mathrm{~cm}$ and moderate to high densities of aquatic macrophytes $16-35 \mathrm{~cm}$ in height (Brooks and Kind 2002). Occasionally the lungfish spawns amongst the submerged roots of riparian trees (e.g. Callistemon sp. or in clumps of partly submerged terrestrial grasses (Kemp 1984, 1986). Structurally complex plant species (such as Vallisneria gigantea, the most commonly used species) with complex branching growth forms or leaf whorls contain higher densities of fertilized eggs than those of simpler growth form.

Most of our knowledge of spawning behaviour comes from studies in the Burnett River (Brooks and Kind 2002) and several earlier accounts from the Brisbane catchment (Kemp 1984). Spawning has been observed in flowing reaches of the lower Boyne River and the upper Burnett River and in a $7 \mathrm{~km}$ riffle and glide section of the Burnett between Ned Churchward Weir and the Burnett Barrage (Brooks and Kind 2002), this reach being the only remaining spawning habitat in the lower $80 \mathrm{~km}$ of the regulated Burnett River main channel (Fig. 2). There is no evidence that lungfish spawn in the existing impoundments on the Burnett River. The Burnett Dam (also called Paradise Dam) and Ned Churchward Weir (Fig. 2) have very steep bank profiles and as balancing storages they tend to have fluctuating water-levels. Under these conditions there is limited opportunity for the growth or persistence of structurally complex macrophyte beds. Brooks (1995) observed that a rapid reduction in water level $(25 \mathrm{~cm})$ in Bingera Weir on the lower Burnett River exposed many shallow spawning areas (predominantly beds of Vallisneria) and caused the death of a large number of fertilized eggs.

Information on spawning behaviour in the Mary River is very limited. Suitable macrophyte beds were rare in the Mary River between 1999 and 2002 as a consequence of a record high flow event in 1999 that scoured river banks (Brooks and Kind 2002). Main channel spawning habitats along the Mary River will be inundated upstream from Traveston Crossing Dam and into tributaries. Shallow inundated embayments with or without aquatic and riparian vegetation, little water movement and large expanses of open water may present very limited options for lungfish spawning.

Juvenile recruitment

Dense beds and banks of vegetation provide suitable microhabitat for developing lungfish embryos and newly hatched lungfish, where they feed on small invertebrates such as microcrustaceans, molluscs and worms. Impoundments with steep profiles and fluctuating water levels typically do not provide suitable nursery habitat and food resources for very young fish and juveniles $(<30 \mathrm{~cm})$ which rely on dense macrophyte beds in very shallow water for many months or years after hatching, until they move into deeper water (Brooks and Kind 2002).

Juvenile lungfish have proved far more difficult to observe and catch than adults. Surveys by different operators in many types of riverine and impounded habitat have usually recorded low numbers, or no juvenile lungfish. From surveys in the Burnett River, Brooks and Kind (2002) concluded that juvenile recruitment of $N$. forsteri has been poor in that river since 1996, coinciding with poor conditions for spawning (i.e. few aquatic macrophytes in shallow water areas) in 1997, 1998 and 1999. Kemp (1986) and Brooks and Kind (2002) suggested that successful lungfish recruitment may not be achieved every year, and may occur only when spawning habitats, food resources and other requirements are met throughout much of the river inhabited by lungfish. 
Growth and longevity

Growth curves for wild lungfish from the Burnett River show that they reach around $40 \mathrm{~cm}$ at 5 years of age (Brooks and Kind 2002). This slow growing species may live for 50 years, with some evidence that lungfish can live up to $80-100$ years in captivity (e.g. the Shedd Aquarium's captive lungfish affectionately known as 'Granddad' is over 80 years old, and is possibly the oldest fish in captivity-see www. fishphotos.org-Australian Museum, Sydney).

Lungfish begin to breed at around 15-17 years of age in males and 20-22 years in the wild. Johnson (2001) remarked that for a long-lived species with naturally low mortality rates, successful spawning and juvenile recruitment are not essential every year, and may only occur irregularly, possibly in medium to long-term cycles, even in natural systems. Such long cycles could easily mask low juvenile recruitment for many years whereas large adults could remain common and the mature populations appear viable for decades without there being any indication of incipient population decline. Recovery from gradual population decline or catastrophic mortality is likely to be very slow.

\section{Movement}

Although generally described as sedentary, the lungfish moves various distances away from its home range (see summary in Pusey et al. 2004). In flowing (unimpounded) sections of the Burnett and Mary rivers adults usually move around one or two pools at night and return each day to a certain resting retreat such as a submerged log, rock or patch of macrophytes (Brooks and Kind 2002). Individual fish may show high fidelity to the same daytime retreat over many consecutive months, even years. Despite their large size, lungfish are capable of traversing very shallow riffle zones (e.g. $12 \mathrm{~cm}$ deep) into other pools to find food and spawning habitat (Kind 2002).

Lungfish living within impounded areas move around far more than those living in naturally flowing reaches, and movements become much more variable at reproductive maturity. There appears to be an annual cycle of movement to and from spawning grounds in the impounded reaches of the Burnett
River main channel, when fish abandon their usual home ranges and are thought to be searching for spawning habitat (Brooks and Kind 2002). Lungfish do not undertake spawning migrations in the unimpounded main channel of the Mary River (Kind 2002).

The movements of lungfish are restricted by natural barriers (waterfalls, gorges and ephemeral river reaches), and by man-made barriers such as dams (wall height $>15 \mathrm{~m}$ ), weirs (wall height $<15 \mathrm{~m}$ ), tidal barrages and road culverts (Berghuis and Broadfoot 2004). Lungfish sampled downstream from Claude Wharton Weir on the Burnett River (Fig. 2) in 2004 were in poorer condition (they were lighter for their length) than those in other parts of the river (Kind et al. 2005). If Traveston Crossing Dam is built it will sever the main river channel upstream from Gympie and effectively isolate upstream and downstream populations of lungfish unless effective fish transfer facilities can be provided (see mitigation options discussed below). Lungfish can be injured or killed when they pass over the top of dam walls and tidal barrages during high water flows (Berghuis and Broadfoot 2004). In the lower Burnett River lungfish have been observed stranded downstream of the tidal barrage, unable to return to freshwater because the fish were too large to use the vertical slot fishway at this barrage (Brooks and Kind 2002; Stuart and Berghuis 2002). Stranding and mortality have also been observed below the Mary River tidal barrage and at the spillway of North Pine Dam after a rapid release of water there (Johnson 2001).

3. The dam will result in the establishment of harmful invasive species

Large dams like Traveston Crossing Dam will transform a lotic system into a lentic one by flooding riverine habitats and creating a large artificial lake. These dramatic changes usually have significant effects on riverine biota and one of them is to facilitate the establishment and spread of alien species of plants and fish (Bunn and Arthington 2002). The ecological implications of invasion by four alien aquatic plants have been outlined above. There are also concerns that the lungfish could be threatened by alien and translocated fishes that have been introduced into the Burnett and Mary catchments (Pusey 
et al. 1993; Kennard 2004; Kennard et al. 2005). The ubiquitous mosquito fish (Gambusia holbrooki) preys on the eggs and juveniles of native fishes and competes with small species for food and habitat (Arthington and Lloyd 1989), while other alien species may compete for breeding habitat or contribute to the decline in number of breeding adults (Anon 2006). One of the most worrisome alien species, the Mozambique mouthbrooder or tilapia (Oreochromis mossambicus), has been declared a noxious and threatening alien species in Queensland (Department of Primary Industries and Fisheries, Queensland Government 2008). It is present in Boondooma Dam on the Burnett River and could well become established within the natural range of $N$. forsteri in that catchment, and be spread to the Mary through deliberate or accidental human interventions. This species has high capacity for impacts on native fishes and their habitats by virtue of its flexible habitat and dietary requirements, ability to breed early at small body sizes under harsh environment conditions, parental care of eggs and young, capacity for rapid population increase and spread (Arthington and Blühdorn 1994; Arthington et al. 1994; Canonico et al. 2005). Oreochromis mossambicus is wellestablished in North Pine Dam and other impoundments in south-east Queensland where the species captures small fish as part of a generalist diet composed of detritus, benthic invertebrates and the flower heads of Hydrilla verticillata, one of the native macrophytes found in preferred lungfish habitat (Arthington et al. 1994).

\section{Mitigation options}

Several studies on the Mary River and its major tributaries have explored the importance of the natural flow regime to fish and aquatic vegetation (Pusey et al. 1993; Bunn and Arthington 2002; Mackay et al. 2003). Based on these and many other information sources, a Water Resource Plan (WRP) has been developed for the Mary River catchment. The WRP has set environmental flow targets for flora and fauna at various nodes throughout the catchment (Brizga et al. 2004; Kennard 2004). These flow targets include adequate low flows, constraints on low flow spells, release of higher in-channel flows and small floods, combined into a modified flow regime that is intended to maintain the habitat, food resources, passage and breeding requirements of fish and other biota throughout the Mary River. The EIS for Traveston Crossing Dam asserts that these targets will be achieved by appropriate water releases from the dam, and that they will maintain lungfish spawning sites, juvenile habitat and recruitment processes downstream (SKM 2007). The maintenance of adequate low flows will be most important because, contrary to folklore, $N$. forsteri is incapable of surviving complete desiccation, and unlike the African lungfish Protopterus, it does not secrete a mucous cocoon and bury itself in bottom muds during dry seasons or drought. The Australian lungfish can only survive out of water for a few days using the lung, but only if the surface of the skin is constantly moist. It tends to use the lung for respiration when it is active and requires more oxygen, usually at night while foraging, when swimming in floodwaters and when spawning (Grigg 1965; Kind et al. 2002).

The EIS (SKM 2007) promises that fish bypass facilities will be provided at Traveston Crossing Dam similar to those at Burnett Dam on the Burnett River, i.e. a 'state-of-the-art' fish lift (see diagram and description in Meredith 2008a, b) to enable upstream movement past the dam wall. A sluice in the dam wall is planned to allow downstream fish passage. The Burnett Dam fish lift is already operating and successfully transferring a range of fish species upstream, however the number of lungfish that entered the downstream lock and exited upstream on one monitoring occasion was very low (precise data cannot be published at this time). An audit of the Burnett Dam by the Department of Environment, Water, Heritage and the Arts (which approved the construction of this dam) recently reported that it is only partially compliant with Commonwealth requirements under the EPBC Act-failure to comply being related to the poor performance of the fish transfer device which has operated infrequently since it was commissioned. Low water levels in the storage of Burnett Dam during the current drought have interfered with operation of the fish lift, a possibility apparently overlooked during the design phase.

As well as the installation of fish transfer facilities to enable movements upstream and downstream into suitable living and breeding habitats, consideration will be given to the translocation of $N$. forsteri individuals and/or juveniles reared from broodstock 
into areas of the Mary catchment where natural and man-made barriers limit or prevent access to potentially suitable habitat. Population enhancement based on the release of fish bred in captivity does not necessarily guarantee beneficial outcomes for endangered fishes, mainly because of the genetic bottlenecks associated with small population size (Anders 1998; Frentiu et al. 2001). Even if these problems can be overcome by selective breeding, the supplementation of declining populations is a last resort solution, and frequently a far more expensive option than habitat and ecosystem restoration activities that address the principal causes of endangerment (habitat loss, alien species, river impoundment and flow regulation) rather than tinkering with the symptoms (Anders 1998; Meffe 1992; Helfman 2007).

\section{Conclusions}

Neoceratodus forsteri has already been listed as a vulnerable species under the Commonwealth EPBC Act and is the subject of a Recovery Plan that will guide management actions and permissible activities in and around lungfish habitats. A first principle of recovery planning is to protect existing habitats and to maintain or restore landscape and local processes that generate and maintain habitat structure (Knight and Arthington 2008). Traveston Crossing Dam will inevitably interfere substantially with such recovery actions for the lungfish. It will destroy and fragment essential larval, juvenile and adult habitats along the main channel of the Mary River and several tributaries, and while the new lacustrine habitats created will probably support mature lungfish they appear unlikely to be suitable for lungfish spawning and for juvenile recruitment, which appear to be sporadic and unsustainably low.

Multiple weirs and dams along the Burnett River have progressively removed lungfish breeding habitat and disrupted movement. In 2002, 41\% of the known range of the lungfish within the main channel of the Burnett River $(128 \mathrm{~km})$ had been inundated by impoundments (Brooks and Kind 2002). The Burnett Dam is presently $45 \%$ full and if it fills completely $55 \%(173 \mathrm{~km})$ of main river channel will be inundated. If Traveston Crossing Dam is built to stage 2, the figure for loss of spawning habitat in the Mary River may reach $40 \%$, including main channel and tributary habitats and the regulated reaches downstream from Traveston Crossing Dam.

The Australian lungfish is vulnerable to reduced river flows, dry spells and complete desiccation. Traveston Crossing Dam will store incoming river flows and regulate natural patterns of river flow below the dam, with potentially severe consequences for lungfish if low flow spells become more frequent and prolonged. Lungfish require very long periods to recover from catastrophic mortality and population decline as a consequence of their slow growth rate, long generation time and the high vulnerability of larval and juvenile lungfish.

Even though sophisticated fish transfer facilities are proposed to allow upstream and downstream movements of lungfish in the Mary catchment there is no guarantee that the fish lift and sluice will be effective enough to maintain the original levels of population connectivity and genetic mixing. The ecological and genetic consequences of population fragmentation and isolation could be significant for a species of such low genetic diversity and high extinction risk

$N$. forsteri is not genetically diverse, a feature shared with other endangered species and often associated with population declines (Frankel and Soulé 1981) and high extinction risk (Frankham 1996). Frentiu et al. (2001) noted that low levels of genetic variation at two classes of neutral, independent markers suggest low variability across the whole lungfish genome, probably including loci linked to fitness and resistance to disease. Low levels of genetic variation may lead to inbreeding depression, population decline, reduced evolutionary potential and high extinction risk (Frankel and Soulé 1981; Frankham 1996). Reduced genetic variability may also be a symptom as well as a cause of extinction (Dunham et al. 1999). Low genetic diversity implies low potential for evolutionary adaptation to changing and new environmental conditions, while the low recruitment of juvenile lungfish, their slow growth and long generation times will severely limit the species' capacity to adapt rapidly to sudden changes in environmental conditions associated with the new dam.

In conclusion, building a large storage reservoir on the main channel of the upper Mary River appears highly likely to risk significant decline and fragmentation of important natural populations of the Australian lungfish. This risk seems far too high for a species 
already declared vulnerable and urgently in need of recovery in its remaining natural habitats.

Gene Helfman from the University of Georgia and author of the world's most authoritative and comprehensive text on fish conservation (Helfman 2007) offered this comment in his submission to the global lungfish petition:

'The Australian lungfish serves as a flagship species with high international visibility. Australia's standing with respect to biodiversity conservation will be significantly diminished if this species is further threatened by more impoundments. In an era when dams are being decommissioned throughout the developed world, more thoughtful alternatives to Australia's water needs seem appropriate' (see http:// www.thepetitionsite.com/1/a-very-special-fish-austra lian-lungfish-under-threat).

Acknowledgements I thank David Noakes, Editor-in-Chief of Environmental Biology of Fishes, for the invitation to write this paper and for his comments on an earlier draft. Two anonymous referees and my colleagues Peter Kind, Brad Pusey, Mark Kennard and Cassie James are also thanked for assistance with data, illustrations (plate, photo and map) and their helpful suggestions to improve the manuscript. This paper is a product of research on the ecology of rivers under threat supported by the eWater Cooperative Research Centre, the National Water Commission, several State agencies and the former Land and Water Resources Research and Development Corporation (LWRRDC). Final thanks go to the DIVERSITAS Freshwater Cross-cutting Network and Robert Naiman for leading global efforts to halt the decline of freshwater biodiversity.

Open Access This article is distributed under the terms of the Creative Commons Attribution Noncommercial License which permits any noncommercial use, distribution, and reproduction in any medium, provided the original author(s) and source are credited.

\section{References}

Anders PJ (1998) Conservation aquaculture and endangered species. Can objective science prevail over risk anxiety? Fisheries 23(11):28-31

Anon (2006) Matters of National Environmental Significance. EPBC Act Policy Statement Number 1.1, Significant Impact Guidelines. Commonwealth of Australia. www. deh.gov.au/epbc

Arthington AH, Blühdorn DR (1994) Distribution, genetics, ecology and status of the introduced cichlid, Oreochromis mossambicus, in Australia. In: Dudgeon D, Lam P (eds) Inland Waters of Tropical Asia and Australia: Conservation and Management, Mitteilungen (Communications), Societas Internationalis Limnologiae (SIL) 24:53-62
Arthington AH, Lloyd LN (1989) Introduced Poeciliidae in Australia and New Zealand. In: Meffe GK, Snelson FF (eds) Evolution and ecology of livebearing fishes (Poeciliidae). Prentice-Hall, New York, pp 333-348

Arthington AH, Milton DA, McKay RJ (1983) Effects of urban development and habitat alterations on the distribution and abundance of native and exotic freshwater fish in the Brisbane region, Queensland. Aust J Ecol 8:87-101 doi:10.1111/j.1442-9993.1983.tb01597.x

Arthington AH, Blühdorn DR, Kennard MJ (1994) Food resource partitioning by Oreochromis mossambicus, and two native fishes in a sub-tropical Australian impoundment. In: Chou LM, Munro AD, Lam TJ, Chen TW, Cheong LKK, Ding JK, Hooi KK, Khoo HW, Phang VPR, Shim KF, Tan CH (eds) The Third Asian Fisheries Forum. Asian Fisheries Society, Manila, Philippines, pp 425-428

Arthington AH, Brizga SO, Choy SC, Kennard MJ, Mackay SJ, McCosker RO et al (2000) Environmental flow requirements of the Brisbane River Downstream from Wivenhoe Dam. South East Queensland Water Corporation Ltd and Centre for Catchment and In-Stream Research. Griffith University, Brisbane, $539 \mathrm{pp}$

Berghuis AP, Broadfoot CD (2004) Upstream passage of Queensland lungfish at Ned Churchward Weir fishlock. Report to Dept. of State Development by the Queensland Fisheries Service, 25 pp

Brizga S, Arthington AH, Choy S et al (2004) Mary Basin Draft Water Resource Plan: Environmental Conditions Report, Final Report vol 2. Queensland Department of Natural Resources, Brisbane

Brooks S (1995) Short-term study of the breeding requirements of lungfish (Neoceratodus fosteri) in the Burnett River with specific reference to the possible effects of the proposed Walla Weir. Report by the Queensland Department of Primary Industries. Fisheries Division, Brisbane

Brooks SG, Kind PK (2002) Ecology and demography of the Queensland lungfish (Neoceratodus forsteri) in the Burnett River, Queensland with reference to the impacts of Walla Weir and future water infrastructure development. Queensland Department of Primary Industries, Fisheries Division, Brisbane, Report No. QO02004

Bunn SE, Arthington AH (2002) Basic principles and consequences of altered hydrological regimes for aquatic biodiversity. Environ Manage 30:492-507 doi:10.1007/ s00267-002-2737-0

Canonico GC, Arthington A, McCrary JK, Thieme ML (2005) The effects of introduced tilapias on native biodiversity. Aquat Conserv: Mar Freshwat Ecosyst 15:463-483 doi:10.1002/aqc.699

Daeschler EB, Shubin NH, Jenkins FA (2006) A Devonian tetrapod-like fish and the evolution of the tetrapod body plan. Nature 440:757-763 doi:10.1038/nature04639

Department of the Environment Water, Heritage and the Arts (2008) Neoceratodus forsteri in Species Profile and Threats Database, Department of the Environment, Water, Heritage and the Arts, Canberra. http://www.environment.gov.au/sprat

Department of Primary Industries and Fisheries, Queensland Government (2008) Noxious fish. Declared noxious species. http://www2.dpi.qld.gov.au/fishweb/1347.html

Duivenvoorden LJ (1998) Aquatic Flora of the Burnett River in relation to the Walla Weir- Post Construction Phase: 1998. 
Report for Queensland Department of Natural Resources, Resource Development and Planning: Brisbane. University of Central Queensland, Rockhampton

Dunham H, Peacock M, Tracy CR, et al (1999) Assessing extinction risk: integrating genetic information. Conserv Ecol 3(1). article 2.

Editorial (2006) Save the lungfish. Nature 442:224

Frankel OH, Soulé ME (1981) Conservation and Evolution. Cambridge University Press, Cambridge

Frankham R (1996) Inbreeding and conservation: a threshold effect. Conserv Biol 9:792-799 doi:10.1046/j.15231739.1995.09040792.x

Frentiu FD, Ovenden JR, Street R (2001) Australian lungfish (Neoceratodus forsteri: Dipnoi) have low genetic variation at allozyme and mitochondrial DNA loci: a conservation alert? Conserv Genet 2:63-67 doi:10.1023/A:1011576116472

Grigg GC (1965) Studies on the Queensland lungfish, Neoceratodus forsteri (Krefft) III. Aerial respiration in relation to habits. Aust J Zool 13:413-421 doi:10.1071/ ZO9650413

Helfman GS (2007) Fish conservation a guide to understanding and restoring global biodiversity and fishery resources. Island Press, Washington, DC

Johnson JW (2001) Review of the draft lungfish report (Ecology and demographics of lungfish (Neoceratodus forsteri) and general fish communities in the Burnett River, Queensland with reference to the impacts of Walla Weir and future water infrastructure development, by Steven G. Brooks \& Peter Kind). Report for Burnett Water, 4 July 2001. Queensland Museum, Brisbane

Joss JM (2007) A Very Special Fish-Australian Lungfish under Threat. http://www.thepetitionsite.com/1/a-very-specialfish-australian-lungfish-under-threat.

Kemp A (1984) Spawning of the Australian lungfish, Neoceratodus forsteri (Krefft) in the Brisbane River and in Enoggera Reservoir, Queensland. Mem Queensl Mus 1:391-399

Kemp A (1986) The biology of the Australian lungfish, Neoceratodus forsteri (Krefft 1870). J Morphol 1(Supplement):181-198 doi:10.1002/jmor.1051900413

Kemp A (1991) Australian Mesozoic and Cainozoic Lungfish. In: Vickers-Rich P, Monaghan JM, Baird RF, Rich TH (eds) Vertebrate Palaeontology of Australasia, Pioneer Design Studio Pty. Ltd., Victoria. pp 465-497

Kemp A (1995) Threatened fishes of the world: Neoceratodus forsteri (Krefft, 1870) (Neoceratodontidae). Environ Biol Fishes 43:310 doi:10.1007/BF00005863

Kennard MJ (2004) Freshwater fish. Appendix H In: Brizga S, Arthington A.H., Choy S, Duivendoorden L, Kennard M, Maynard R, Poplawski W (eds) Mary Basin Water Resource Plan (WRP), Environmental Conditions Report. Queensland Department of Natural Resources, Brisbane

Kennard MJ, Arthington AH, Pusey BJ, Harch BD (2005) Are alien fish a reliable indicator of river health? Freshw Biol 50:174-193 doi:10.1111/j.1365-2427.2004.01293.x

Kind PK (2002) Movement patterns and habitat use in the Queensland lungfish Neoceratodus forsteri (Krefft 1870). $\mathrm{PhD}$ Thesis, University of Queensland
Kind PK, Grigg GC, Booth DA (2002) Physiological responses to prolonged hypoxia in the Queensland lungfish Neoceratodus forsteri. Respir Physiol Neurobiol 132(2):179-190

Kind PK, Brooks SG, Piltz SA (2005) Burnett River Dam Baseline Lungfish Monitoring 2004/2005. Department of Primary Industry and Fisheries, Queensland

Knight J, Arthington AH (2008) Distribution and habitat associations of the endangered Oxleyan pygmy perch, Nannoperca oxleyana Whitley, in eastern Australia. Aquatic Conservation Marine and Freshwater Ecosystems. Published online in Wiley InterScience (www.interscience. wiley.com) doi:10.1002/aqc.936

Krefft G (1870) Description of a gigantic amphibian allied to the genus Lepidosiren from the Wide-Bay district, Queensland. Proc Zoological Soc 16:221-224

Mackay SJ, Arthington AH, Werren G (2001) Ecological impacts of weirs in the Pioneer Catchment, Queensland. In: The Way Forward on Weirs. (S. Blanch, Ed.). Inland Rivers Network, NSW. pp 39-58.

Mackay SJ, Arthington AH, Kennard MJ, Pusey BJ (2003) Spatial variation in the distribution and abundance of submersed aquatic macrophytes in an Australian subtropical river. Aquat Bot 77:169-186 doi:10.1016/S0304-3770(03)00103-7

McGrath C (2006) Swirls in the stream of Australian environmental law: debate on the EPBC Act. Environ Plann Law J 23:165-184

Meffe GK (1992) Techno-arrogance and halfway technologies: salmon hatcheries on the Pacific Coast of North America. Conserv Biol 6:350-354 doi:10.1046/j.1523-1739. 1992.06030350.x

Meredith P (2008a) To dam, or not to dam? Aust Geogr (Jan):102-111

Meredith P (2008b). To Paradise and beyond. Griffith Review Winter 2008:61-84

Nelson JS (2006) Fishes of the World, 4th edn. Wiley, New York

Pearson H (2006) Dam project threatens living fossil. Nature 442:232-233 doi:10.1038/442232b

Pusey BJ, Arthington AH (2003) Importance of the riparian zone to the conservation and management of freshwater fish: a review. Mar Freshw Res 54:1-16 doi:10.1071/MF02041

Pusey BJ, Arthington AH, Read MG (1993) Spatial and temporal variation in fish assemblage structure in the Mary River, S. E. Queensland: the influence of habitat structure. Environ Biol Fishes 37:355-380 doi:10.1007/BF00005204

Pusey BJ, Kennard MJ, Arthington AH (2004) Freshwater Fishes of North-Eastern Australia. CSIRO, Collingwood, Victoria, $684 \mathrm{pp}$

SKM (2007) Traveston Crossing Dam Environmental Impact Statement. Executive Summary and Section 8.6.5.2 (Lungfish). October 2007

Stuart IG, Berghuis AP (2002) Upstream passage of fish through a vertical-slot fishway in an Australian subtropical river. Fish Manag Ecol 9:111-122 doi:10.1046/j.13652400.2002.00285.x

Tokita M, Okamoto T, Hikida T (2005) Evolutionary history of African lungfish: a hypothesis from molecular phylogeny. Mol Phylogenet Evol 35:281-286 doi:10.1016/j.ympev. 2004.11.025 